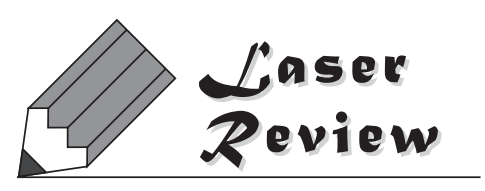

\title{
脳組織バイアビリティーの光学的モニタリング
}

\author{
川内 聡子 \\ 防衛医科大学校 防衛医学研究センター 情報システム研究部門 (テ359-8513 埼玉県所沢市並木3-2)
}

\section{Optical Monitoring of Brain Tissue Viability}

\author{
Satoko KAWAUCHI \\ Division of Biomedical Information Sciences, National Defense Medical College Research Institute \\ 3-2 Namiki, Tokorozawa, Saitama 359-8513
}

(Received January 16, 2012)

\begin{abstract}
Light-scattering signal, which is sensitive to cellular/subcellular structural integrity, is a potential indicator of brain tissue viability, because metabolic energy is used in part to maintain the structure of cells in the brain. First, we examined how light scattering changed during viability loss of the brain without hemoglobins, for which diffuse reflectance measurements were performed for a rat global ischemic brain model made by perfusing the whole blood. After oxygen/glucose deprivation, we observed a unique triphasic scattering change (TSC), which almost coincided with cerebral ATP decrease in the brain. Secondly, we showed that TSC can be detected even in the presence of blood by using NIR light in a rat hypoxic brain model. The brain recovered when oxygen was restored during the TSC. These results suggest the usefulness of light-scattering signals for monitoring brain tissue reversibility after serious brain diseases and injuries including acute ischemic stroke and traumatic brain injury.
\end{abstract}

Key Words: Light scattering, Brain, Tissue viability, Anoxic depolarization, Diffuse reflectance measurement

1. はじめに

脳は虚血や低酸素に対して極めて脆弱な組織であり短 時間で機能停止に陥るが, 機能停止は必ずしも組織の不 可逆的変性を意味せず, 血流再開などにより組織を救済 しうる ${ }^{1)}$. しかしながら, 現在このような組織救済の可 否の境界(クリテイカルタイムゾーン)をリアルタイムに 判定できる技術は無い. 我々は, 病態に伴う脳組織バイ アビリティーの変化を, 内因性光学信号 (Intrinsic optical signal: IOS) を用いて非侵襲かつリアルタイムに捉える技 術の確立をめざしている. IOSは組織・細胞の生理学 的, 生化学的, 形態学的な状態を反映した光吸収 · 散乱 に関わる信号であり，蛍光標識や造影剤を使用すること なく真に非侵襲なリアルタイム診断が可能である.

組織のバイアビリティーの源はエネルギー代謝すなわ ちATP(adenosine triphosphate)の産生であり，ATPは主と してミトコンドリアの内膜にある電子伝達系の4つの酵 素を電子が伝達する際に合成される。このATPをin vivo で直接計測することは困難であるが，興味深いことに， 電子伝達に異常が起きると末端酵素のシトクロムc オキ シダーゼ (cytochrome c oxidase: $\mathrm{CcO}$ )が, 酸化一還元に より光の吸収変化を起こす. $\mathrm{CcO}$ の活性中心であるheme $\mathrm{aa}_{3}$ と $\mathrm{CuA}$ はそれぞれ $605 \mathrm{~nm}, 830 \mathrm{~nm}$ 吸収ピークを持 つが, 酸素欠そ等による還元が起こると, 前者の吸収は 増大，後者の吸収は低下する2).

光による脳組織バイアビリティー計測に関する研究と しては, 上記の電子伝達機構の解明に関わったChanceら が，1980年代にネコとイヌを用いin vivoにおいてCcOの 光吸収特性からエネルギー代謝計測を試みたのが有名で ある3). その後複数のグループにより研究が進められた が4-8), 組織中で強い光吸収を有するへモグロビンの影 響により信号の解釈が容易でなく, $\mathrm{CcO}$ の光吸収を指標 とした診断法は今なお開発途上にある。

一方我々は, 細胞のエネルギーが細胞・細胞小器官の 形態維持にも利用されることに着目し ${ }^{1)}$, これらの形態 変化を反映する光の散乱が有効な指標になりうると考え た。一般に光の散乱は, 生体組織中の散乱体である細 胞・細胞小器官の形態変化を鋭敏に捉えうる 体透過性の高い可視〜近赤外の領域では, 脳組織の等価 光散乱係数は吸収係数よりも2桁高いことから ${ }^{10)}$, 光散 乱は血液存在下においても感度の高いバイアビリティー の指標になると期待される.

以上に基づき, 我々は, 光散乱信号を脳組織バイアビ リティーの指標として利用すべく，これまで動物モデル 
を対象とした研究を進めてきた。本稿では, これらにつ いて紹介するとともに, 本技術の今後について展望した い.

\section{2. バイアビリティー低下に伴う三相性光散乱変化}

我々は，脳組織のバイアビリティーが低下するとき光 の散乱はどのように変化するのかについて調べるため, ヘモグロビンによる光吸収の影響を除外したラット脳虚 血モデル(脱血による酸素とグルコースの供給を停止す るモデル)を対象に, 上記 $\mathrm{CcO}$ の光吸収変化と光散乱信 号の同時計測を試みた ${ }^{111}$. 麻醉下にラット頭部を固定 し, 露出させた脳表に一対の光ファイバ(コア径800 $\mu \mathrm{m}$, 中心間隔 $2 \mathrm{~mm}$ ) を接触させ, LED 可視光 (中心波 長 $528 \mathrm{~nm}$ おうび $621 \mathrm{~nm}$ ) 拉よびLDの近赤外光(ピーク波 長 $830 \mathrm{~nm}$ )を脳組織に入射し, 拡散反射光を計測した (Fig. 1). 得られた信号を波長解析し, $\mathrm{CcO}$ の酸化一還 元に関する等吸収波長である $620 \mathrm{~nm}$ 付近において光散乱 変化を, また $605 \mathrm{~nm}$ 抒よび $830 \mathrm{~nm}$ の光吸収変化からそ れぞれheme aa $a_{3}$ およびCuAの還元をモニタリングした.

その結果, 酸素とグルコースの供給停止から一定時間 後, まずheme $\mathrm{aa}_{3}$ の還元が開始し, 続いて光散乱信号が 三相性の変化(増加一減少一増加)を伴って増大, その途 中から $\mathrm{CuA}$ の還元が進行するという興味深い現象を観測 した (Fig. 2) ${ }^{11}$. ささらにこの三相性光散乱変化 (triphasic scattering change: TSC) と脳組織のATP濃度との関係を 調べたところ, ATP濃度はTSCの前後で有意に減少し (Fig. 3 (a)), またTSCの開始はATP低下に先立つことが わかった $(F i g .3(\mathrm{c}))^{12}$. これらの結果は光散乱, すなわ ち細胞の形態変化がミトコンドリアのエネルギー代謝と 密接に関係することを示している.ささらに脳の電気的機 能停止(脳波の停止) はTSCに先立って起き(Fig. 3 (b)), 機能停止後しばらく細胞の形態は維持されること, また DCポテンシャル(細胞外直流電位)の計測からTSCは虚 血性脱分極によるものであることが示唆された(Fig. 3 $(\mathrm{d}))^{12}$. 虚血性脱分極は細胞膜内外のイオンが激しく流 出入する現象で, 細胞外直流電位の急激な減少を特徵と し, 細胞・細胞小器官の形態変化を伴い, 長く続くと不 可逆的な神経細胞死につながることが知られている ${ }^{13)}$.

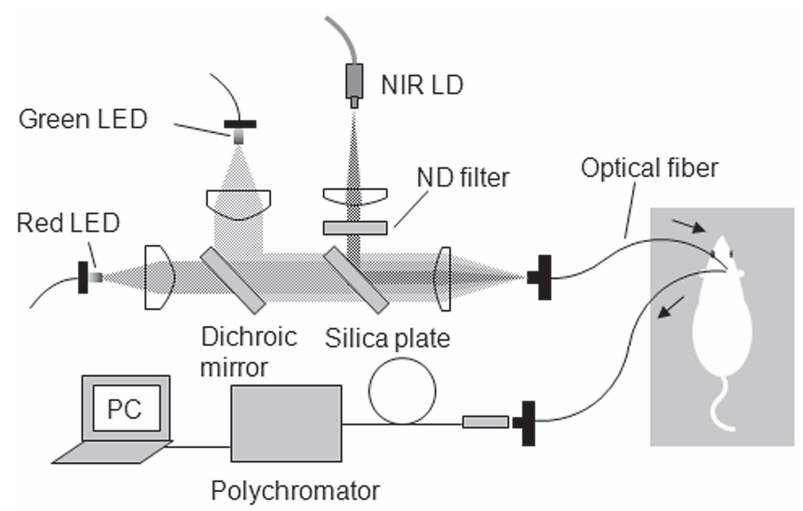

Fig. 1 Diagram of the experimental setup for diffuse reflectance measurement of rat brains. ${ }^{11)}$

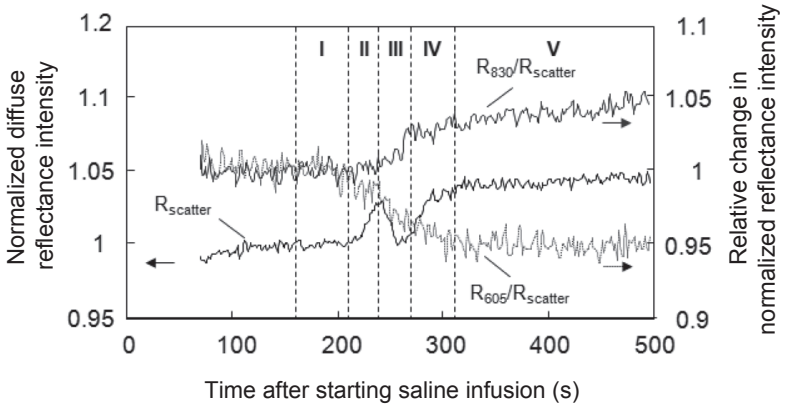

Fig. 2 Time courses of light scattering signal (diffuse reflectance intensity at $\left.623 \mathrm{~nm}: \mathrm{R}_{623}\right)$ and absorption signals related to the reduction of heme $\mathrm{aa}_{3}\left(\mathrm{R}_{605}\right)$ $\left.\mathrm{R}_{623}\right)$ and $\mathrm{CuA}\left(\mathrm{R}_{830} / \mathrm{R}_{623}\right)$ in cytochrome c oxidase after starting saline infusion at $24{ }^{\circ} \mathrm{C} .{ }^{11)}$ Decrease in $R_{605} / R_{623}$ represents increase in the tissue absorption at $605 \mathrm{~nm}$ due to reduction of heme $\mathrm{aa}_{3}$, while increase in $\mathrm{R}_{830} / \mathrm{R}_{623}$ represents decrease in the tissue absorption at $830 \mathrm{~nm}$ due to reduction of $\mathrm{CuA}$.

透過型電子顕微鏡観察の結果, 光散乱変化後の組織にお いて樹状突起の膨化やミトコンドリアの変形が見られ， ミトコンドリア内部ではクリステの偏りやマトリックス の収縮が観察された $(\text { Fig. 4 })^{11)}$ 。観測された散乱変化は, このような細胞・細胞小器官レベルの形態変化によるも のと推察された.

\section{3. 経頭蓋骨的in vivo光散乱計測}

次に上記のTSCがin vivo(血液存在下)に扔いても検出 可能かどうか調べるため, ラット脳低酸素モデルを対象 に広帯域光源 (タングステンランプ, 400〜1000 nm)を 用いて拡散反射光計測を行った ${ }^{14)}$. ラットにマスクを装 着し，吸気ガスを空気から窒素ガスに切り替えることに より，自発呼吸下で脳を低酸素にし，散乱が支配的な近 赤外光を用いて組織の散乱変化を検出した．同時にへモ グロビンの等吸収波長である $569 \mathrm{~nm}$, 脱酸素化へモグ ロビン (deoxy-Hb) の吸収が優位な560 nmにおける信号 変化から, それぞれ総へモグロビン (total-Hb), 脱酸素 化へモグロビン (deoxy-Hb)の濃度変化を求めた。 モンテ カルロシミュレーションにより, 上記光ファイバ配置で は光計測領域の最大深度は波長 $560 \mathrm{~nm}$ で $0.8 \mathrm{~mm}$, 波長 $805 \mathrm{~nm}$ で $1.5 \mathrm{~mm}$ と見積もられたことから，いずれも大 脳皮質の情報を取得していると考えられる。

Fig. 5 (a)に，窒素ガス吸入による波長730，805およ び $830 \mathrm{~nm}$ に掞ける拡散反射光強度の時間変化(時刻 $t=$ $0 \mathrm{~s}$ で規格化)を示す，窒素吸入開始後， $805 \mathrm{~nm}$ の信号強 度は直後にわずかに増加した後に減少し，時刻約 $150 \mathrm{~s}$ に扔いて三相性の変化(増加一減少－増加）を示し，その 後高いレベルに保たれた。波長 $730 \mathrm{~nm}$ 抒よび $830 \mathrm{~nm}$ の 信号変化も同時刻において三相性の変化を示しその後増 大した，低酸素開始直後( $50 \mathrm{~s})$ の信号変化は急激な低 酸素に伴う血液増加による散乱変化を表していると考え られる。

これらと同時計測した脳のへモダイナミクスに関する 

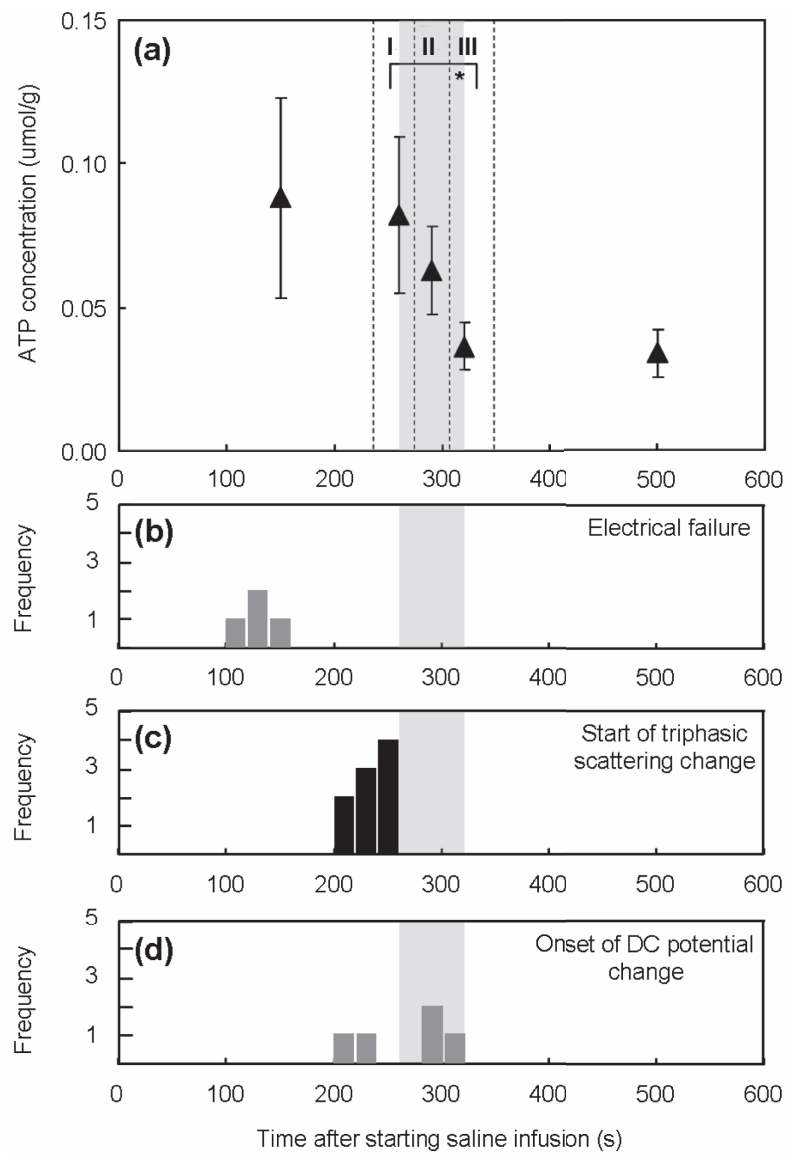

Fig. 3 ATP concentration of cerebral cortex tissue as a function of time after starting oxygen/glucose deprivation by saline infusion. ${ }^{12)}$ An asterisk $(*)$ indicates statistical significance $(p<0.05)$. Each plot represents the mean value with standard deviation. Mean starting time points of each phase of the triphasic scattering change (TSC) and its ending time point are shown by four vertical dashed lines: 236 $( \pm 15)$ s, $273( \pm 17)$ s and $306( \pm 15)$ s for starting time points of the first, second and third phases, respectively, and $348( \pm 19) \mathrm{s}$ for the ending time point of the TSC. Frequency histograms of the time points of cessation of EEG activity $(n=4)(b)$, the start of TSC $(n=9)$ (c), and the onset of DC potential change $(n=5)(\mathrm{d})$. The time zone of ATP exhaustion is shown by a gray shadow.
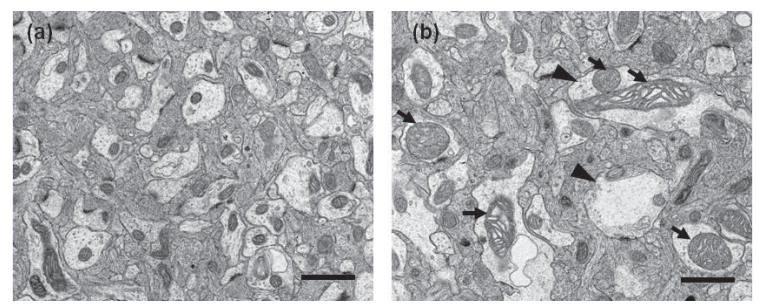

Fig. 4 Transmission electron microscopic images of cortical surface tissues at (a) $50 \mathrm{~s}$ and (b) $350 \mathrm{~s}$ after starting saline infusion, corresponding to before and after the triphasic scattering change, respectively. ${ }^{11)}$ Image (b) shows remarkably enlarged dendrites (arrowheads) and enlarged, deformed mitochondria with irregular cristae (arrows). Scale bar in each panel represents $1 \mu \mathrm{m}$.
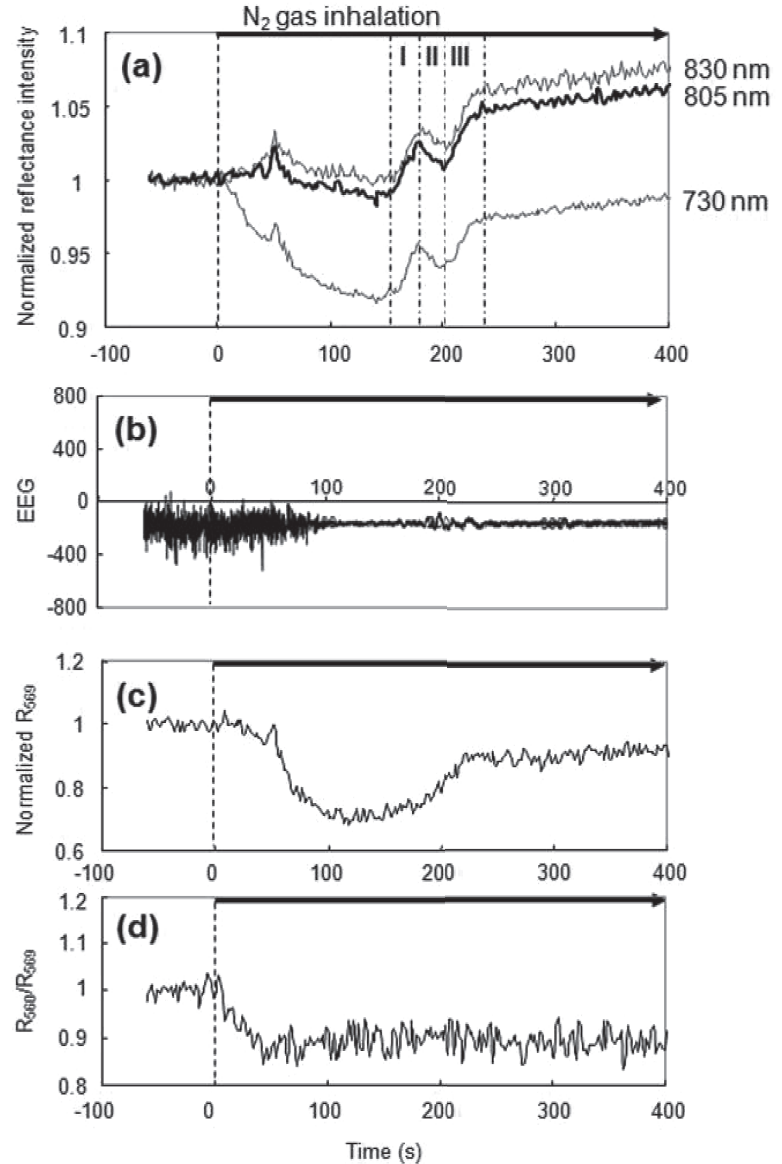

Fig. 5 Time courses of normalized diffuse reflectance intensities at 730, 805 and $830 \mathrm{~nm}$ (a), EEG activity (b), normalized diffuse reflectance intensity at $569 \mathrm{~nm}\left(\mathrm{R}_{569}\right)$, indicating relative change in total$\mathrm{Hb}$ concentration (c), and normalized diffuse reflectance intensity at $560 \mathrm{~nm}\left(\mathrm{R}_{560}\right)$ divided by $\mathrm{R}_{569}$, indicating relative change in deoxy-Hb concentration (d). Nitrogen gas inhalation was started at $t=0$.

IOSの変化をFig. 5 (c) と (d)に示す. (c) はtotal-Hb濃度変 化を表す信号(信号の減少がtotal-Hbの増加を表す), (d) はdeoxy-Hb濃度変化を表す信号(信号の減少がdeoxy-Hb の増加を表す)である。窒素吸入開始後, ヘモグロビン の脱酸素化は急激に進行し, 約 $t=40 \mathrm{~s}$ でほぼ一定になる と (Fig. 5 (d)), 続いて total-Hb (血流量)が急激に増加し (Fig. $5(\mathrm{~d}))$, 約 $t=120 \mathrm{~s}$ をピークに減少に転じた。この 血液量の変化は, 急激な低酸素に反応した血流増加とそ れに続く血流低下を表している。上述した近赤外の拡散 反射光強度の三相性変化 (Fig. 5 (a)) は, この血流増加 のピークを過ぎた時間帯に観察され，脳組織内のへモグ ロビンの脱酸素化から約110 s後(Fig. 5 (d)), EEGの消 失すなわち脳の電気生理学的機能停止(脳波の平坦化) か ら約60 s後に開始した(Fig. 5 (b))。これらの結果は実験 を行った全12匹のラットで再現して見られ，三相性変化 の開始時間は $128 \pm 14 \mathrm{~s}$ ，開始から終了までの時間は $64 \pm 10 \mathrm{~s}$ であった ${ }^{14)}$.

三相性変化の各相の信号変化率の波長依存性を調べた ところ，いずれにおいても波長650-850 nmの領域では波 長依存性が小さかったことから, 近赤外の信号変化は主 
として散乱変化由来であることが示された ${ }^{14)}$. すなわ ち, 我々が脱血モデルで観測した酸素とグルコースの供 給停止後の三相性光散乱変化 (TSC) (Fig. 2) が, 血液存 在下に拈いても観測できることが確認できた。 この結果 に基づき,ささらに我々は光散乱信号が脳組織の可逆・不 可逆性とどのように関係するか調べるため, 自発呼吸に よるラット脳の再酸素化を試み, 光散乱変化と再酸素化 によるラット救済の可否との関係につき調べた ${ }^{14)}$.

\section{4. 光散乱信号と脳組織可逆・不可逆性の関係}

上述したラット脳低酸素モデルで観測された三相性光 散乱変化(TSC) は, 脱血モデルで観察されたのと同様に 虚血性脱分極によるものと推察される。第一相の散乱増 大は，脱分極に伴う細胞内外のイオンの流出入によるも ので，このときまだATPの低下は開始していないと考え られる ${ }^{12}$ ，それに続く第二相の散乱減少は，イオンのよ り戻しによるものと考えられるが, このプロセスは大量 のエネルギーを消費するため ${ }^{15)}$ ，ATPは急減し細胞膜の $\mathrm{Na}^{+} / \mathrm{K}^{+}$ポンプが破綻, これにより再びイオンの移動が起 き散乱が増大した(第三相)と推察される。これより我々 は，少なくとも第二相までは細胞は可逆的な状態にある と予想した。 各相で再酸素化したラットの生存率をFig. 6 に示す.TSC開始前に再酸素化したラットの生存率は $100 \%(n=8, n$ は対象ラットの総数)であり, 第一相，第 二相，第三相における生存率は，それぞれ $43 \%(n=14)$, 10\% $(n=10), 20 \%(n=10)$, TSC後に再酸素化したラッ 卜の生存率は $0 \%(n=8)$ であった。第一相から第三相の 間, ラットの生死は確率的であり ${ }^{14)}$, TSCが脳組織救済 のためのクリテイカルタイムゾーンとなることが示され た。このことは光散乱信号が脳組織バイアビリティーの 有効な指標となりうることを示唆している.

TSCの間, ラットの生存が確率的であり，また予想に 反して第三相でもラットが生存したのは, 散乱変化の 原因と考元られる虚血性脱分極が大脳皮質の局所に発 生し不均一に広がるため ${ }^{16}$, 光計測の位置により散乱変 化開始時間が変化することが影響している可能性があ る. 同モデルを対象にCCDカメラを用いて虚血性脱分 極の光散乱イメージングを試みたところ, 脱分極に由来

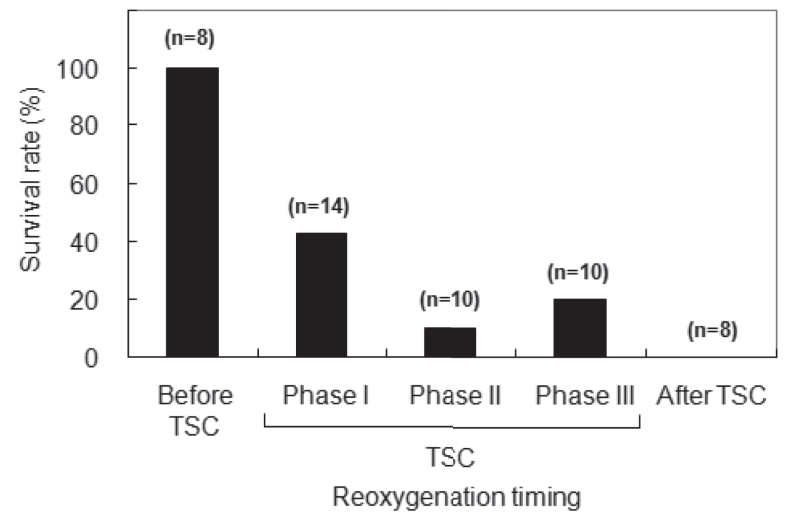

Fig. 6 Survival rates of rats by reoxygenation before, during, and after the triphasic scattering change.

する光散乱の波は再現性よく両側頭部局所に始まり, 時 間とともに脳全体に伝播・拡大することがわかった (Fig. 7 $)^{17)}$. また本実験に扔いて救済できなかったラッ トでは，いずれも酸素再投与後に脳のへモダイナミクス の回復が得られなかった．これには，TSCの原因と考え られる虚血性脱分極が，血管虚脱や血管収縮を伴う現象 であることが関係している可能性がある ${ }^{18}$. 今後, 光散 乱変化の時空間的な拡がりと血管の健全性㧍よび組織の 可逆・不可逆性との関係につき明らかにし, 臨床応用を 視野に研究を進める計画である。

\section{5. おわりに}

本研究は，ラット全脳虚血モデル(脱血モデル)におい て観測されたバイアビリティー低下に伴う三相性光散乱 変化が, 脳組織のATP濃度の低下とほぼ同期すること, またその散乱変化は虚血性脱分極によるものであること を示した，そしてinvivoにおけるラット脳低酸素モデル を用いた多波長拡散反射計測により，このような光散乱 変化が近赤外光を用いることにより血液の存在する条件 に扔いても観測可能なことを明らかにした。ささらに再酸 素化実験により，三相性光散乱変化は組織救済のための クリティカルタイムゾーンとなりうることが示唆され た。 今後この散乱変化のメカニズムと組織の可逆・不可 逆性との関倸の詳細を明らかにすることで, 本光散乱計
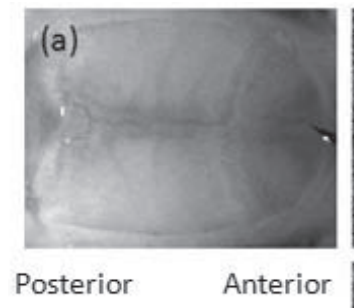
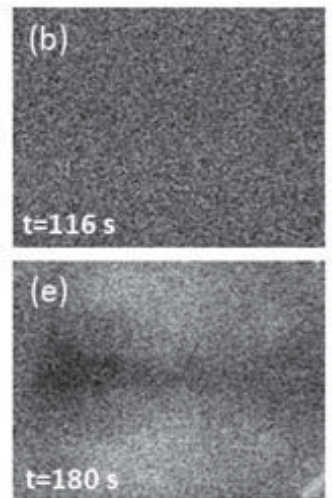
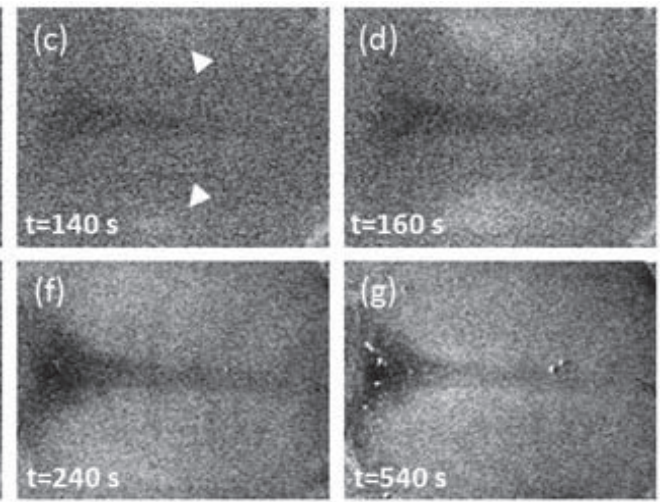

Fig. 7 NIR reflectance images of the rat brain before (a) and after nitrogen gas inhalation started at $t=0 \mathrm{~s}(\mathrm{~b}-\mathrm{g}) .{ }^{17)}$ (b-g) Difference images (after minus before). Arrowheads in (c) indicate regions of scattering wave generation. 
測による脳組織バイアビリティー診断技術を確立したい と考えている. また光散乱を用いた診断法は, 広く脱分 極のモニタリングへの応用が期待される．各種病態に起 因する激しい脱分極波の発生は大量のエネルギーを消費 するため組織に有害である。このような脱分極波の重要 例として, 虚血性脳梗塞の治療標的として注目される梗 塞層周囲のペナンブラ領域で起きる脱分極 (Peri-infarct depolarizations: PIDs), 頭部外傷およびクモ膜下出血に おいて関与が指摘される拡延性脱分極 (spreading depolarization)等がある ${ }^{19-22)}$ 。 これらを対象とした光散乱イメー ジングは，脳循環代謝の病態解明にも重要な役割を果た すものと期待される.

\section{謝 辞}

本研究は, 防衛医科大学校情報システム研究部門 佐藤 俊一博士, 同脳神経外科学講座苗代弘博士と共同 で行われたものである。また前所属の同医用工学講座 石原美弥博士，菊地 眞博士には多くのご支援をいただ いた。本研究の一部は (財) 福田記念医療技術振興財団, (財) 興和生命科学振興財団の研究助成を得て実施され た。関係各位に深く感謝の意を表します。

\section{参考文献}

1) K. A. Hossmann: Ann. Neurol. 36 (1994) 557.

2) D. C. Wharton and Q. H. Gibson: in Biochemistry of copper ed. J. Peisach (Academic Press, New York, 1966) p.235.

3) M. Tamura, O. Hazeki, S. Nioka, B. Chance, and D. S. Smith: Adv. Exp. Med. Biol. 222 (1988) 359.

4) M. Tsuji, H. Naruse, J. Volpe, and D. Holtzman: Pediatr. Res. 37 (1995) 253.
5) G. Nollert, T. Shin'oka, and R. A. Jonas: Thorac. Cardiovasc. Surg. 46 (1998) 167.

6) C. E. Cooper, M. Cope, R. Springett, P. N. Amess, J. Penrice, L. Tyszczuk, S. Punwani, R. Ordidge, J. Wyatt, and D. T. Delpy: J. Cereb. Blood Flow Metab. 19 (1999) 27.

7) Y. Kakihana, A. Matsunaga, K. Tobo, S. Isowaki, M. Kawakami, I. Tsuneyoshi, Y. Kanmura, and M. Tamura: Eur. J. Cardiothorac. Surg. 21 (2002) 434.

8) I. Tachtsidis, M. Tisdall, T. S. Leung, C. E. Cooper, D. T. Delpy, M. Smith, and C. E. Elwell: Physiol. Meas. 28 (2007) 199.

9) J. R. Mourant and I. J. Bijio: in Biomedical Photonics Handbook ed. T. Vo-Dinh (CRC Press, Boca Raton, 2003) (Chap. 29.)

10) P. van der Zee, M. Essenpreis, and D. T. Delpy: Proc. SPIE 1888 (1993) 454.

11) S. Kawauchi, S. Sato, H. Ooigawa, H. Nawashiro, M. Ishihara, and M. Kikuchi: Appl. Opt. 47 (2008) 4164.

12) S. Kawauchi, S. Sato, H. Ooigawa, H. Nawashiro, M. Ishihara, and M. Kikuchi: Neurosci. Lett. 459 (2009) 152.

13) M. Balestrino: J. Neurosci. Methods 59 (1995) 99.

14) S. Kawauchi, S. Sato, Y. Uozumi, H. Nawashiro, M. Ishihara, and M. Kikuchi: J. Biomed. Opt. 16 (2011) 027002.

15) T. Takano, G. F. Tian, W. Peng, N. Lou, D. Lovatt, A. J. Hansen, K. A. Kasischke, and M. Nedergaard: Nat. Neurosci. 10 (2007) 754.

16) C. R. Jarvis, T. R. Anderson, and R. D. Andrew: Cereb. Cortex 11 (2001) 249.

17) S. Kawauchi, S. Sato, Y. Uozumi, H. Nawashiro, M. Ishihara, and M. Kikuchi: Proc. SPIE 7907 (2011) 79070M.

18) H. K. Shin, A. K. Dunn, P. B. Jones, D. A. Boas, M. A. Moskowitz, and C. Ayata: J. Cereb. Blood Flow Metab. 26 (2006) 1018.

19) C. Dohmen, O. W. Sakowitz, M. Fabricius, B. Bosche, T. Reithmeier, R. I. Ernestus, G. Brinker, J. P. Dreier, J. Woitzik, A. J. Strong, and R. Graf; Co-Operative Study of Brain Injury Depolarisations (COSBID): Ann. Neurol. 63 (2008) 720.

20) A. J. Strong, M. Fabricius, M. G. Boutelle, S. J. Hibbins, S. E. Hopwood, R. Jones, M. C. Parkin, and M. Lauritzen: Stroke 33 (2002) 2738.

21) J. P. Dreier, S. Major, A. Manning, J. Woitzik, C. Drenckhahn, J. Steinbrink, C. Tolias, A. I. Oliveira-Ferreira, M. Fabricius, J. A. Hartings, P. Vajkoczy, M. Lauritzen, U. Dirnagl, G. Bohner, and A. J. Strong; COSBID study group: Brain 132 (2009) 1866.

22) C. Iadecola: Nat. Med. 15 (2009) 1131.
内因性光学信号 (intrinsic optical signal)

一般に, 生体組織に由来する内因性の光吸収ないし散 乱信号のことを言う. 前者の代表は, 酸素化・脱酸素化 ヘモグロビン，エネルギー代謝に関わるミトコンドリア の電子伝達系末端酵素シトクロムcオキシダーゼ, 脂質, 水等に由来する信号であり, 後者は, 生体組織中の光散 乱体である細胞や細胞小器官の形態 (大きさ, 形状, 密 度, 屈折率等)を反映する信号である。このような内因
性光学信号を利用することにより，生体組織・細胞の生 理学的, 生化学的, 形態学的情報を非侵襲的かつリアル タイムに計測・イメージングすることが可能となる。医 学生物学分野においては, 造影剤や蛍光標識など, 外因 性物質を利用した診断・イメージングが多用されている が, 内因性光学信号を用いた計測・イメージングは簡便 であり, 安全性が高いという特長を有する。(川内聡子) 